\title{
Integrating Developing Country Manufacturing Industries into Global Supply Chain
}

\author{
Fasika Bete Georgise ${ }^{1}$, Thoben Klause-Dieter ${ }^{2}$, Marcus Seifert ${ }^{2}$ \\ ${ }^{1}$ School of Mechanical \& Industrial Engineering, Hawassa University (Ethiopia) and International Graduate School \\ of Dynamics for Logistics, University of Bremen (Germany) \\ ${ }^{2}$ Bremer Institut für Produktion und Logistik. GmbH-BIBA (Germany) \\ geo@biba.uni-bremen.de, tho@biba.uni-bremen.de, s@@biba.uni-bremen.de
}

Received: April 2013

Accepted: January 2014

\section{Abstract:}

Purpose: Due to globalized nature of manufacturing activities, the arena of competition and competitiveness advantage is moving from firms towards supply chains and networks. With the recent advancement of information and communication technologies this participation are becoming as common business practice in developed countries firms. Companies are more integrating into the world market for the global nature of the sourcing, manufacturing and distribution. These changes create both challenges and opportunities for the manufacturing industries in developing countries. The objective of this paper is to examine the level of interorganizational and intra-organizational supply chain integration practices in developing country, Ethiopia.

Design/methodology/approach: An industrial questionnaire survey is used to collect the current practices of the manufacturing industries in Ethiopia as an example of the developing countries. Descriptive statistics is primarily used for the analysis.

Findings: Results show a low level of supply chain relationship both in intra and inter organizational supply chain integration level among members. Accordingly, such issues require 
much attention to facilitate a greater integration within the global supply chains for the Ethiopian manufacturing industries.

Research limitations/implications: The paper focuses on examining the practices of Ethiopian manufacturing industries empirical data. The interpretation of results should be taken with prudence.

Originality/value: The manufacturing industry in developing countries (MIDC) has been a part of the global supply chains for long time as a supplier of raw material and manufacturer of primary products. Currently, the MIDC is trying to access the different markets segment of the world even with new products starting from their local market to the complex and dynamic international market. Nevertheless, their supply chains are inefficient and hence, their competitiveness level far from the norm expected. The supply chain integration will bring positive impacts and benefits for manufacturers in developing countries if it adopted properly.

Keywords: developing countries, supply chain integration, manufacturing industry

\section{Introduction}

Recently, the global market fierce competition, the fast introduction of new products with shorter life cycle, growing customer satisfaction and ongoing development of information and communication technologies (ICT) and transportation infrastructure have forced business to invest in and direct attention to their supply chains. There is a high pressure on businesses to decrease costs and enhance customer satisfaction levels in order to remain in competitive position. This pressure is no exception for the manufacturing industries in developing countries in some cases it is fiercer. Supply chain management is becoming strategic tools for improving firms performance and their competitiveness position. Companies versus companies have replaced with supply chain versus supply chain competitiveness strategy. However, the number of companies that have truly integrated their supply chains to take advantages of this opportunity is still small (Hosseini, Aziz \& Sheikhi, 2012; Özdemir \& Aslan, 2011).

The MIDC has participating in global supply chain for long times mainly as suppliers of raw material and in recent times as supplier of basic consumers goods. Figure 1 shows the typical manufacturing supply chain involving developing and developed countries. Firms in developed countries have employed different approach to collaborate, share benefits and risks in the form of partnerships. This effort has not considered the firms in developing countries. Hence, the anticipated improvement of the entire supply chain has been unsuccessful (Simchi-Levi, Kaminsky \& Simchi-Levi, 2003). 
The aim of this paper to assesses the supply chain integration level in one of the developing country, Ethiopia and recommends future research directions. The paper begins by: (a) review the literature on supply chain integration, (b) explore global supply chain and the participation of the MIDC, and (c) analyze and discuss the empirical field findings. Hence, finally, it provides a better understanding in the area of supply chain integration in the MIDC. In doing so, the section 2 of this paper focuses on supply chain integration and section 3 reported the about the global supply chain. The field findings and discussions are described in section 5 where as the conclusions and future research agenda is describes in section 6.

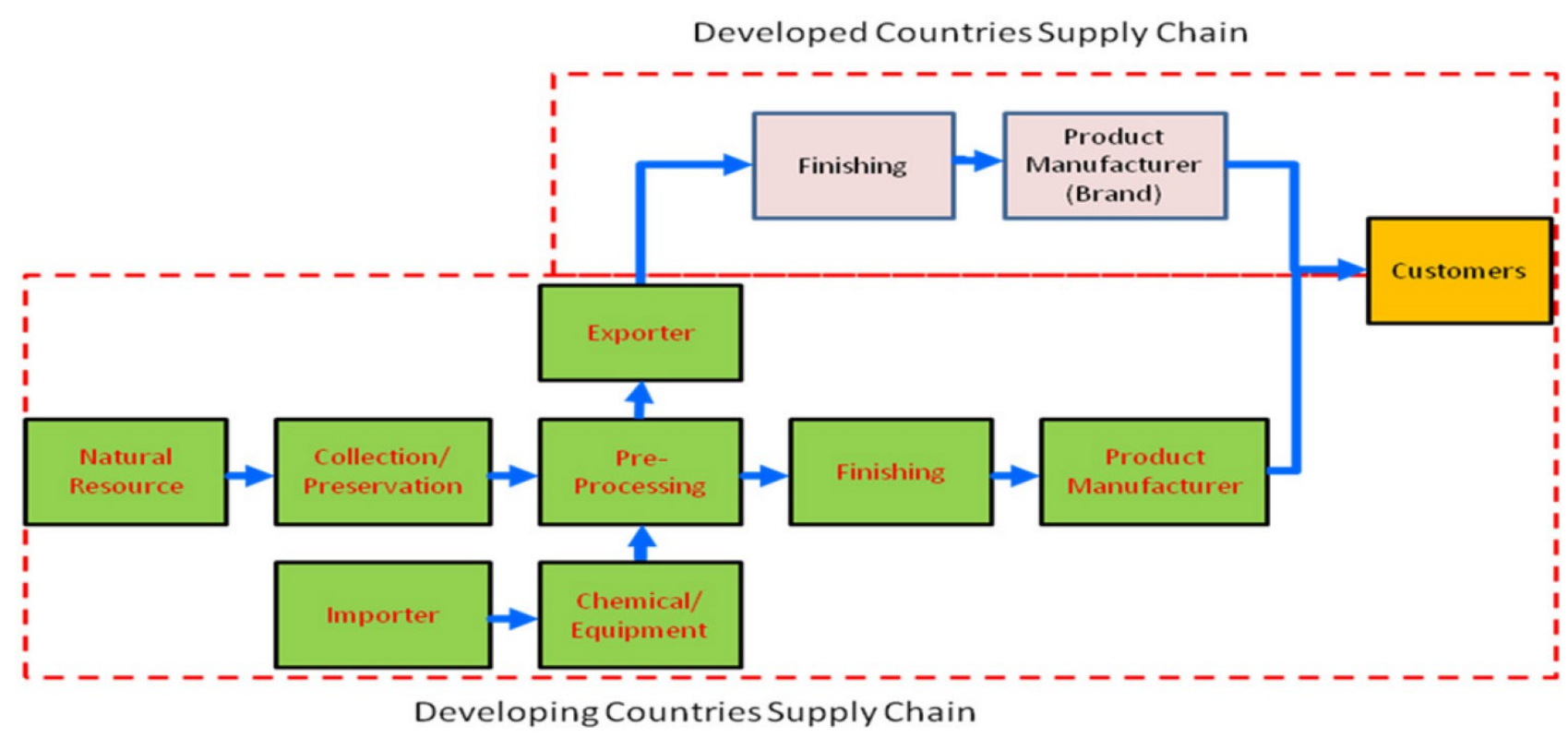

Figure 1. Typical supply chain

\section{Supply Chain Integration}

This section focuses on the concepts of supply chain (SC) integration, its importance, level, benefits, cost and challenges of integration. In other words, how firms have come to integrate their material and information flow activities and processes inside the organizations and with their supply chain partners. In order the organization to fully benefit and implement supply chain management concepts and it is important to integrate efficiently with suppliers, manufacturers, warehouses and other intermediate value-adding partners. Lambert and Cooper (2000) demonstrates the importance of cross-functional integration via marketing with examples of several cases (Lambert \& Cooper, 2000). Especially manufacturers have to give high attention to integration so that sourcing, production and distribution are synchronized with customer demand, thereby reducing overall system or pipeline costs and satisfying service level requirements (Hugo, Badenhorst-Weiss \& Van Biljon, 2004). SCM revolves around efficient integration of suppliers, manufacturers, warehouses and stores and ultimately final 
users. The Figure 2 demonstrates both internal and external integration for the firms' full integration processes.

For this research study we have adopted Monczka, Handfield, Giunipero, Patterson and Waters (2010) definition supply chain integration as follows: "The process of incorporating or bringing together different groups, functions, or organizations, either formally or informally, physically or by information technology, to work jointly and often concurrently on a common businessrelated assignment or purpose". Wisner, Leong and Tan (2006) also confirmed and acknowledged that activities in the supply chain are well coordinated when members of the supply chain work together during their sourcing, production, delivery and inventory decisions that impact on the competitiveness of the supply chain (Wisner et al., 2006). Hence, successful supply chain integration happen when the players realize that supply chain management must become part of all the business' strategic planning processes based on the final customers' needs and what the supply chain as a whole does well. Next section discusses four topics on integration: level of integration, ICT and integration, benefits and costs of integration and challenges of integration.

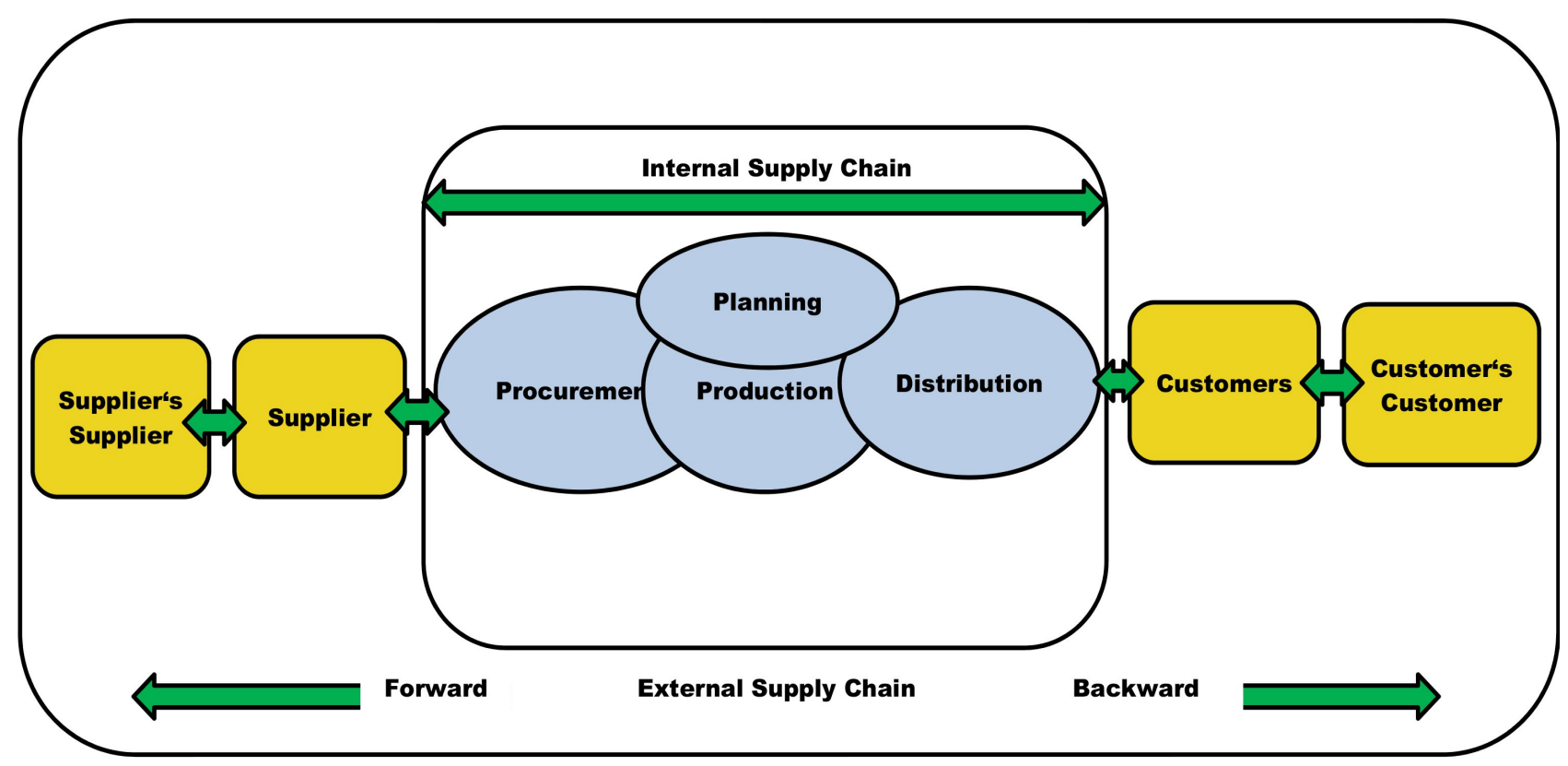

Figure 2. Supply chain integration

\subsection{Levels of Integration}

Different research results have presented on supply chain integration, competition capabilities and business performance. Stevens (1998) was one of the pioneers on the supply chain integration. He identified four stages of supply chain integration. The first stage was represented by the fragmented operations within the individual company. The characteristic of 
second stage was limited integration between adjacent functions, e.g. purchasing and materials control. In the third stage, the integration required the internal integration of the end-to-end planning in the individual company. Finally, in the last stage: stage IV represented the true supply chain integration including upstream to suppliers and downstream to customers (Stevens, 1989).

Frohlich and Westbrook (2001) also show the importance of strategic decision on the extent of integration with the upstream and downstream members of the supply chains in manufacturing industries. They have introduced the concept of "arcs of integration" also acts as a trigger point for the flourishing supply chain integration literature. Figure 3 shows the extent of integration with form of an arc. Depending on the complexity of souring and market spectrum, manufacturing industries decide to engage in relatively little or larger extent of integration with suppliers and customers. In their study, examined the effect of supply chain integration level on performance, classified the supply chain integration in five classes (inward-, periphery-, supplier-, customer-, outward-facing) according to the integration intensity of the company towards the customer direction and the supplier direction. They examined the performance differences between these five classes. As a result, it is found that outward-facing companies which were defined as the most comprehensive integration level of supply chain, have better performance in many criteria's than the other companies in other classes (Frohlich \& Westbrook, 2001).

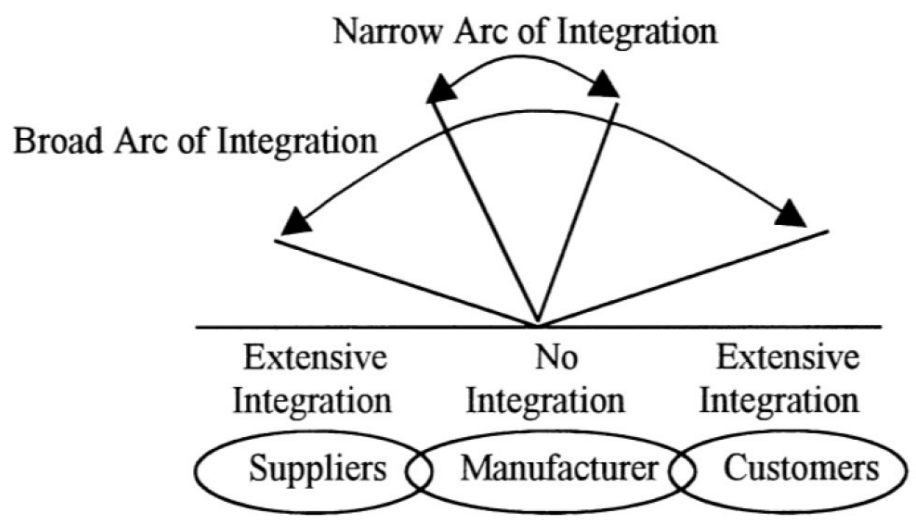

Figure 3. Arcs of integration (Frohlich \& Westbrook, 2001)

In their research, Bowersox, Closs and Stank (2001) have classified integration in a SC context in six different types. These are customer integration, internal integration, material and service supplier integration, technology and planning integration, measurement integration and relationship integration (Bowersox et al., 2001). 
In other research by McLaren (2006) integrates and improves upon the two dominant supply chain maturity models that prepared by (Moncrieff \& Stonich, 2001; Roloff, Gailius, Ibarra \& Polese, 2001) by avoiding the problems of the "maturity" concept and making it operational on the various levels more clear (Mclaren, 2006). In his conference publication defines "the level of supply chain integration as the degree to which the processes, systems, and strategies used in a supply chain are jointly coordinated among the partners in a supply chain". Poirier and Bauer (2001) describe four levels of supply chain maturity that could be used to measure supply chain integration although their text provides little guidance on how to make it operational and the terminology is not well defined (Poirier \& Bauer, 2001). Moncrieff and Stonich (2001) also present a four-level supply chain maturity model; however, their "External Integration" level does not differentiate between sequential dependencies (i.e., linked organizations) and pooled dependencies (i.e., integrated organizations) (Moncrieff \& Stonich, 2001). To address these shortcomings, the research done by (Mclaren, 2006) presents a new typology informed by the aforementioned studies (see Table 1). In order to maximize the differentiability between the levels of supply chain integration, the typology uses five levels as shown in the table and a terminology that is simple, precise, and agrees with industry standard terms such as those of the Supply Chain Council's (2005) SCOR Model (SCC, 2010; Mclaren, 2006).

\begin{tabular}{|c|c|}
\hline Level Characteristics & Observable Pattern \\
\hline $\begin{array}{l}\text { Level I } \\
\text { Functional Focus }\end{array}$ & $\begin{array}{l}\text { - Discrete processes managed at the department level } \\
\text { - Performance measured at functional level }\end{array}$ \\
\hline $\begin{array}{l}\text { Level II } \\
\text { Internal Integration }\end{array}$ & $\begin{array}{l}\text { - Company-wide processes managed at both functional and cross-functional process } \\
\text { levels } \\
\text { - Performance measured at the company, process, and diagnostic levels }\end{array}$ \\
\hline $\begin{array}{l}\text { Level III } \\
\text { Linked Network }\end{array}$ & $\begin{array}{l}\text { - Core processes managed internally; info sharing with external partners } \\
\text { - Outsourcing of non-core processes. } \\
\text { - Metrics defined by one firm. Joint performance monitoring and correction with } \\
\text { partners. }\end{array}$ \\
\hline $\begin{array}{l}\text { Level IV } \\
\text { Integrated Network }\end{array}$ & $\begin{array}{l}\text { - End-to-end process mgmt., coordination, \& collaboration with external partners. } \\
\text { - Alignment of business objectives and processes of each partner } \\
\text { - Joint metrics definition, monitoring, and correction with external partners. }\end{array}$ \\
\hline $\begin{array}{l}\text { Level V } \\
\text { Optimized Network }\end{array}$ & $\begin{array}{l}\text { - Standardized, modular processes coordinated in real-time and executed by most } \\
\text { capable partners. } \\
\text { - Standardized performance metrics monitored and corrected jointly at the company, } \\
\text { process, and diagnostic levels. }\end{array}$ \\
\hline
\end{tabular}

Table 1. Characteristics of SC integration level (Mclaren, 2006)

Manufacturing firms use different integration strategies based on their levels of integration. As mentioned previously, the integration level of firms is divided into five different levels. Many firms in developed countries have moved towards linked network (level III) and a survey by PE Consulting in 1997 found that 57 percent of companies had some form of integration of their 
supply chains. More than 90 percent of the companies expected further integration, with a quarter looking for "Integrated Network" systems (level IV). Even though the benefits of external integration may be clear, there are many practical difficulties of achieving them. However, little research observed about the supply chain integration in the developing countries (PE Consulting, 1997). One typical research done by Han, Kwon, Bae \& Sung (2002) in Korea discussed the level of the supply chain integration. The MIDC has very low and limited capabilities. Many firms simply do not trust other members of the supply chain, and they reluctant to share information. The research done by Han et al. (2002) suggested it is safe to say that supply chains integration in developing countries are between stage I and stage II (Han et al., 2002).

\subsection{Enablers of Supply Chain Integration}

Information and communication technology (ICT) is an important enabler of efficient supply chain integration, and many ICT applications have recently gained popularity. This is due to their ability to facilitate, coordinate, and integrate the flow of information across the supply chain. ICT is an enabler for helping supply chain members to establish partnerships for better performance (Jharkharia \& Shankar, 2005). To mention some of the potential ICT applications in developed country firms are Electronic Data Interchange (EDI), Internet and Enterprise Systems such as Enterprise Resource Planning (ERP) and Radio Frequency Identification (RFID). Gunasekaran (2004) explored that ICT is an essential ingredient for business survival and improves the competitiveness of firms (Gunasekaran, 2004).

The findings by McLaren, Head and Yuan (2004) shows that operational efficiency and operational flexibility have direct relationship with SCM information system (McLaren et al., 2004). IT enhances the service level of SCM, improves operational efficiency and information quality (Auramo, Kauremaa \& Tanskanen, 2005).The multiple benefits through successful utilization of Information System also deliver advantage in strategic apart from tangible and intangible ways. The manufacturing industry in developing countries should adopt appropriate ICT tools to leverage business advantage. Effective utilization of ICT tools will provide the MIDC a business environment to operate in, where decisions concerning supply and demand are fully supported by facts and help maximum business value in order to enhance growth and competitiveness.

\subsection{Benefits and Cost of Integration}

Recent research suggests that the higher level of integration with suppliers and customers in the supply chain benefits at greater extent (Jharkharia \& Shankar, 2005; Naude \& Badenhorst- 
Weiss, 2011; Kureshi, 2010). While supplier integration is being increasingly perused around the globe, a comprehensive cost benefit analysis of this phenomenon on case to case basis is required before venturing on it. The most frequently cited reason for firms to engage in supply chain activities is in response to threats and overtures from competitors, both domestic and global. High levels of supply chain performance occur when the strategies at each of the firms fit well with overall supply chain strategies. Thus, each firm must understand its role in the supply chain, the needs of the ultimate customer, the needs of its immediate customers, and how these needs translate into internal operations requirements and the requirements being placed on suppliers. Once these needs for the products and services can be communicated and transported through the supply chain effectively and efficiently, successful supply chain management and its associated benefits will be realized.

Successful supply chain integration occur when the participants realize that supply chain management must become part of all of the firms' strategic planning process, in which objectives and policies are jointly determined based on the final customer's needs and how the entire supply chain does well (Wisner et al., 2006). If a firm is successful in overcoming the significant and complex barriers to integrating supply chains, substantial benefits can be realized ranging from satisfied customers to lower costs to improved financial performance. The range benefits that can accrue to companies that are able effectively manage and work in their supply chains includes (Fawcett \& Magnan, 2001): increased market share and sales growth, reduced inventory levels, reduced SCM costs, decreased order cycle/fulfillment time, increased asset and capital utilization, improved delivery performance, flexibility in meeting/responding to customer requirements, improved return on assets and sales, increased forecast accuracy and reduced cash-to-cash cycle time.

Kureshi (2010) in his research about Pakistanis' manufacturing supply chain integration, he analyzed the costs, complexities, and risks in commissioning and operating of a fully integrated system. He has suggested consequently, most supply chain integration efforts to date have been very limited in scope. Finally, he suggested major costs associated with commissioning and operating an integrated supply chain includes (Kureshi, 2010): lifecycle costs of supply chain integration software and compatible information systems throughout the supply chain, risk of disturbances and stoppages in production, resources and time required for managing, training, and support. As per our discussion in earlier sections, even well managed businesses with strong IT infrastructure and skilled manpower need substantial training support and financial expenditures when adopting such systems. With strong competition in businesses, there is always a better place to spend the scarce resources. 


\subsection{Challenges and Obstacles of Supply Chain Integration}

According to Chopra and Meindhl (2001), a number of factors can impede integration along the supply chain, causing information distortion, longer cycle times, stock-outs, and bullwhip effect, resulting in higher overall cost and reduced customer service capabilities (Chopra \& Meindl, 2001). Under this section we discuss the challenges and obstacles that impede the process integration along the supply chain. Many researchers have mentioned a different kind of classification of supply chain integration challenges based on their own criteria. Stanley, Gregory and Mathew (2005) explained the challenges of supply chain can be classified through the challenge of system relationships (Stanley et al., 2005). The supply chain system has two kinds of relationships, which are the relation between sub-systems, and SCM system and the business strategies. This classification emphasizes the technical challenges that came from the relation between SCM system and internal business strategy. However, this classification bypasses the challenges that the companies may face from external environment.

Using review of the literature, Katunzi (2011) reveals the dominating factors motivating manufacturing firms to engage in supply chain management activities, the barriers they face upon implementation, the strategies or bridges used to overcome the barriers, and the benefits that are available to successful companies. The major barriers identified by his research include; silo mentality, lack of supply chain visibility, lack of trust, lack of knowledge and activities causing the bullwhip effect (Katunzi, 2011).

After extensive reading to the supply chain integration challenges that the literature mentioned in different resources, Awad and Nassar (2010) found that the challenges from three perspectives: technical perspective, managerial perspective and relationships perspective. Finally, Awad and Nassar (2010) have tried to integrate all challenges in a single comprehensive source and then classify these challenges in three main parts. This classification are; first: the Business Micro-environmental challenges, second: the Business Macro-environmental challenges (relationships), and third: The Technical challenges of Supply Chain integration (Awad \& Nasar, 2010). Figure 4 presents this classification of challenges. 


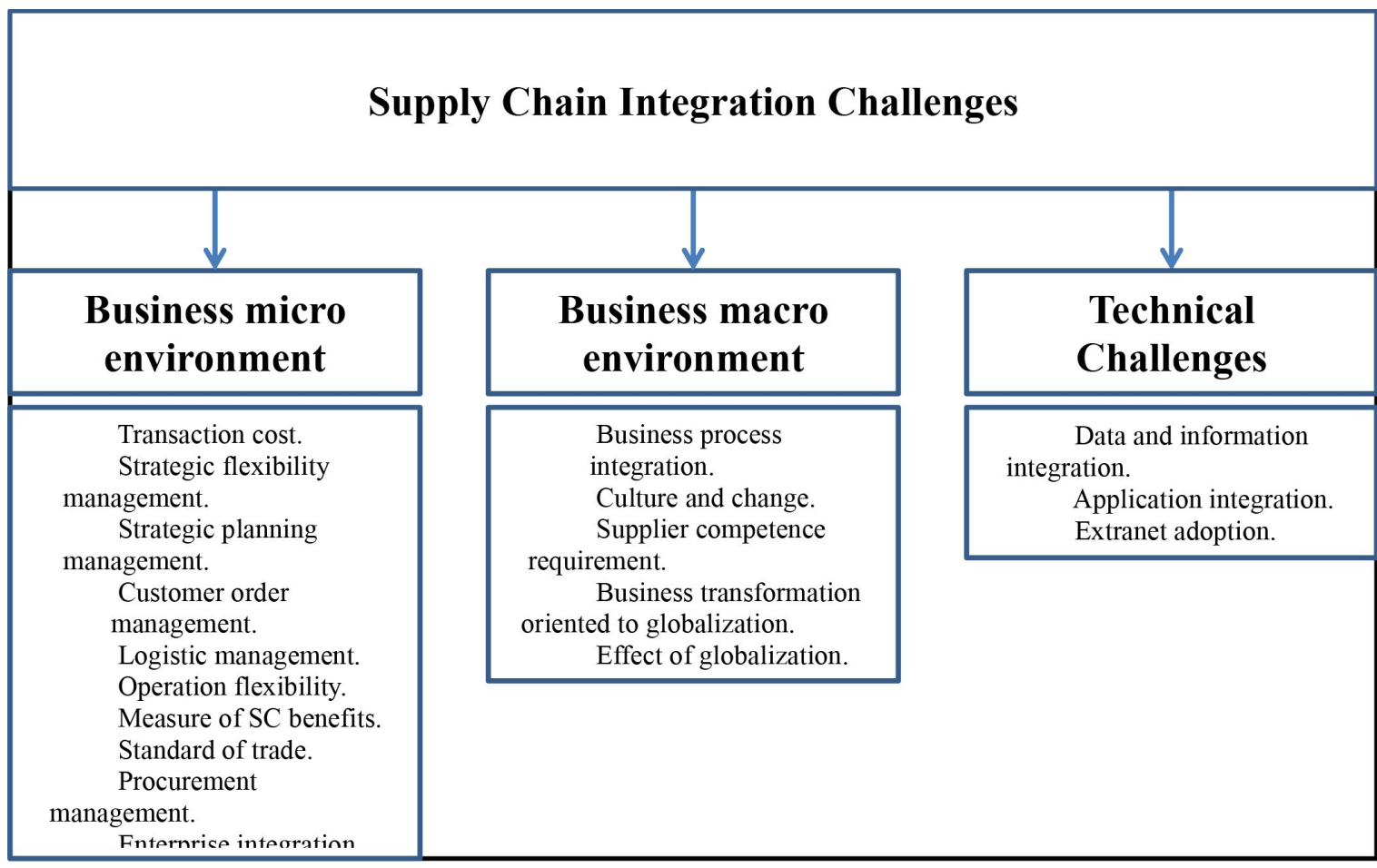

Figure 4. Classification of SC integration challenges (Awad \& Nasar, 2010)

\section{Developing Countries in Global Supply Chain}

Currently, new research results and practical experience in the global supply chain which includes developing countries as one of its players (COMTD, 1996; Ivarsson \& Alvstam, 2005; Fleury \& Fleury, 2001; Humphrey, 2004; Trienekens, 2011). Nowadays, the global supply chains (GSCs) have increasingly gained importance in linking developing countries to international markets. For longer time, the operations of GSCs were limited in only a few selected economic sectors, and were largely confined to developed countries. Up to recent times, the participation developing countries' in GSCs was minor, and limited to as supplier of primary raw material. The recent changes in the global business and improvements in supply chain management, and changes in the industrial structure of the developing countries have allowed GSCs to further integrate developing countries (DC) into production activities (COMTD, 1996).

Global supply chain concepts changes in global business have created different perspectives and forms in the production, logistics, organizational relationship and technological transfer activities. There were a lot of success stories from literature about global supply chain in agribusiness (Trienekens, 2011; Dolan \& Humphrey. 2004; The Conference Board, 2009), production industries (Fleury, and Fleury, 2001; Humphrey, 2004) and others. Typical example for manufacturing industry is the automotive industry where production and distribution networks have emerged globally and where developing-countries (DC) suppliers take their share (Fleury \& Fleury, 2001). Another example from Brazil shows how transfer of technology 
and standards led to changing structures and upgrading of its plastics industry (Fleury \& Fleury, 2001). The above examples also show how the developed countries' technological standards and systems to guide and control processes and flows of goods and information such as HACCP - (Hazard Analysis of Critical Control Points) are increasingly used by developingcountry producers who participate in these supply chains (Trienekens, 2011).

The firms in developing countries are actively participating with substantial share of GSCs' production processes. However, GSCs offer both an opportunities as well as challenges for the developing country enterprises. Even though the global supply chain creates access to market but demand greater efficiency and competence from suppliers. It is therefore, important for developing countries to implement more advanced techniques to enhance their competitiveness focusing in improving their reliability and efficiency. The developing countries have enjoyed preferential market access to developed countries up to present time. The new triangular textile trade provides also an illustration example (Figure 5). Mainly West African countries export raw cotton to China, an important cotton producer which has turned into a long-term net importer (flow 1 in the figure below). Yarn and cloth are sent back mainly to South Africa (flow 2) as an input into low-tech apparel making at Chinese-run factories for the US market (flow 3). A fourth flow consists in imports of cheap clothing to the whole of Africa (Asche \& Schüller, 2008).

There are some research findings that deal on the relationship between supply chain integration and performance in firms of developing countries (Gereffi \& Lee, 2012; Hosseini et al., 2012; Özdemir \& Aslan, 2011, Lee, Kwon \& Severance, 2007; Kim, 2006). Kim (2006) explained the roles and importance supply chain integration for small companies performance improvement compared to the bigger companies could be affected more by supply chain practices and competitive capability. He has suggested that it is more important to focus on supply chain integration in the early phases than later.

One of the related researches was done by Lee et al. (2007). They have assessed the effect of the integration (internally, with suppliers and customers) on the supply chain performance. The final results demonstrate that internal integration is highly related to performance regarding the cost and integration with suppliers is positively affect the reliability and overall performance. 


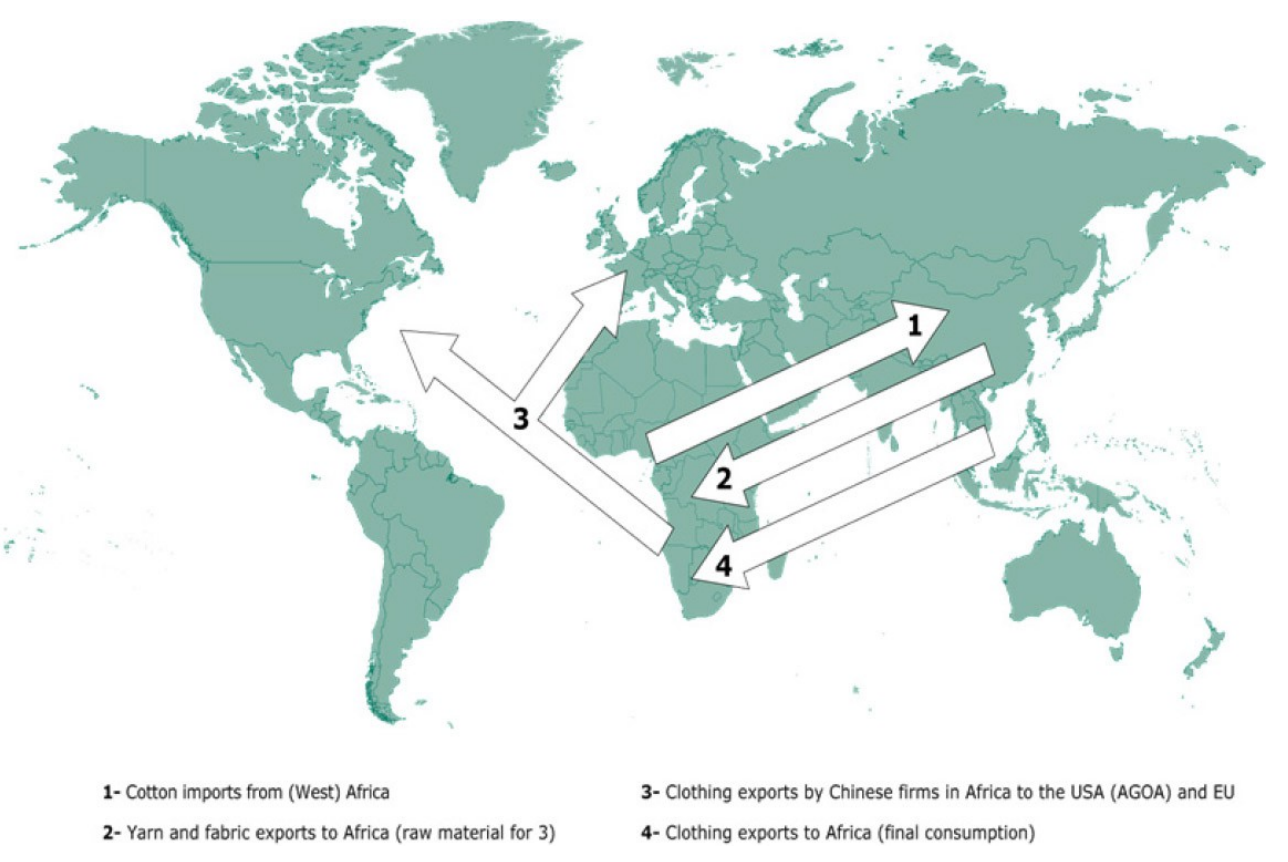

Figure 5. The new Chinese triangular trade in textiles (Asche \& Schüller, 2008)

Hosseini et al. (2012) have investigated the effect of supply chain integration competitiveness capability focus on Iranian food industries. Their findings concluded that internal integration are foundation for further integration with suppliers and customers. Özdemir and Aslan (2011) have also found a similar results on the relationship of supply chain integration, competition capability and business performance.

Gereffi and Lee (2012) in their recent paper have analyzed the current world interest towards to global supply chain. They have found three important trend changes observed in the current global supply chain. The first one is the consolidation of global value chain and the new geography of value creation and capture. Secondly, they have also shown the key roles of global supermarkets and private standards in agri-food supply chains. Finally, the impact of recent economic crisis contributions in shifting end markets and the regionalization of the value chains.

Overall, the literature findings show that companies in developing countries are participating in the global supply chain with different responsibilities. The challenges and obstacles in the developing countries are less investigated compared to the developed countries. It is also observed that very limited literature and research works available about supply chain integration with reference to Ethiopia and similar African countries regarding the benefits and challenges of global supply chain integration process in the manufacturing sector. The research are trying to address the following questions in this study: what is the level Ethiopian manufacturing industries supply chain integration, and what the existing enablers for facilitating the integration processes? 


\section{Research Design and Methodology}

The study was based on the study conducted on the Ethiopian manufacturing industries. These manufacturing industries were producer of basic consumer products. The Primary and secondary data collection methods were employed. Secondary data were based on existing literature on SC integration, while primary data were collected through a self administered questionnaire.

Purposive sampling was used through which two hundred (200) respondents were identified for a self administered questionnaire. Eligibility for participation in the questionnaire survey was based on an employee being a technical professional and working as a manager in the supply chain and production activities. The research instrument covered the profile of company; level of supply chain integration and existing enablers. The Likert scale (that is, 1, 2, 3, and 4) was chosen as it measured attitudes under investigation with agreement- disagreement response scales. The scale is widely used in survey research. Descriptive statistics was used to analyze empirical data. In order to present and collate information from the respondents, data were tabulated, mean and standard deviation calculated.

\section{Preliminary Findings}

A survey package containing a covering letter and the survey questionnaire were sent to 200 Ethiopian manufacturing industries. A total of 42 responses was received, 36 of which were usable, giving a response rate of $17 \%$. Two questionnaires mailed to the director of manufacturing were returned as a result of having incorrect addresses. The sample population was fairly evenly distributed between that who was a producer for export market $(30 \%)$ and those who were a producer for local market (70\%). The respondents' participation as an exporter or local markets producer provides an opportunity to examine supply chain integration only prevalent in organizations. The respondents were spread over a range of industry groups with the majority being such as beverages, chemicals and food industries $22 \%, 19 \%$ and $19 \%$ respectively. The next largest industries were leather and leather products $\&$ wood and wood products industries with $11.3 \%$ each, closely followed by metal and metal products industries $(9 \%)$.

\subsection{Survey findings on the Level SC integration}

This section presents the survey findings related to the supply chain relationship which focused on the level of firms' integration and coordination activities in their business environment. The respondents were asked to rate their organization's level of integration with suppliers, internally, and with customers. The questionnaire was consisted of scaled response from 1 to 4 
such that $1=$ very poor, $2=$ poor, $3=$ high and $4=$ very high. One additional column also was given to those whom may think that techniques were not applicable. The mean and standard deviation (S.D.) were evaluated to compare the level of integration in the firms.

Table 2 shows the respondent firms level of integration with their supplier, customers and within the firm boundaries. The overall level of integration was generally in poor conditions. Cross functional teams information exchange and information exchange with suppliers through internet or web-based technologies were in better level of integration than others. Whereas stable procurement through network and online tracking were in very poor level of supply chain integration.

When we examine the three type of integration, integration within organization boundaries was in better position compare to other forms of integration. Firms' integration with supplier practices was also better than the integration with customers. However, all types of integration were in low practices as compared to the world practices.

\begin{tabular}{|c|c|c|c|}
\hline & $\begin{array}{l}\text { Integrating } \\
\text { factors }\end{array}$ & Mean & $\begin{array}{l}\text { Group } \\
\text { Mean }\end{array}$ \\
\hline \multirow{6}{*}{$\begin{array}{l}\text { With } \\
\text { Suppliers }\end{array}$} & $\begin{array}{l}\text { Information exchange with suppliers through internet or web-based } \\
\text { technologies }\end{array}$ & 2.45 & \multirow{6}{*}{2.20} \\
\hline & Participate level of suppliers in the design stage & 2.35 & \\
\hline & Level of strategic partnership with suppliers & 2.32 & \\
\hline & Participation level of suppliers in the process of procurement and production & 2.29 & \\
\hline & Establishment of quick ordering system & 2.16 & \\
\hline & Stable procurement through network (e.g. electronic data interchange (EDI)) & 1.68 & \\
\hline \multirow{6}{*}{$\begin{array}{l}\text { Within the } \\
\text { Company }\end{array}$} & Cross functional teams information exchange & 2.53 & \multirow{6}{*}{2.21} \\
\hline & Real time inventory management & 2.30 & \\
\hline & Data integration in production processes & 2.29 & \\
\hline & Real time access to logistics-related information & 2.17 & \\
\hline & Data integration among internal functions through network & 2.04 & \\
\hline & Online integrations between production and sales functions & 1.93 & \\
\hline \multirow{5}{*}{$\begin{array}{l}\text { With } \\
\text { Customers }\end{array}$} & Follow up with customers for feedback & 2.31 & \multirow{5}{*}{2.13} \\
\hline & Speed of order processing & 2.28 & \\
\hline & After sales service support & 2.24 & \\
\hline & Integrated demand forecasting & 2.03 & \\
\hline & Online order taking & 1.76 & \\
\hline
\end{tabular}

Table 2. Summary of supply chain integration

\subsection{Survey findings on the existing Enablers and challenges}

Table 3 exemplifies the use of information and communication technologies as enablers, including both hardware and software in the firms. The question was set up also on a four- 
point scaled to measure the level of the enablers' status of each of the items. The scale ranged from 1 to 4 , with 1 = poor performance, 2 = fair performance, $3=$ good performance, and $4=$ excellent performance. The Electronic mail service was the dominant enabler available in the respondent companies. The use of new technologies and software, such as forecast/demand management software; transport/warehouse software and e-procurement; and bar coding/automatic identification system were at poor performance level. Almost half of the respondent companies did not have such types of enablers at all. However, most of companies were interested to adopt such types of enablers in the future. The firms have already started a program in adopting and implementing for local software.

\begin{tabular}{|l|c|c|}
\hline \multicolumn{1}{|c|}{ ICT infrastructure: including both hardware and software in the company } & Mean & S. D. \\
\hline Electronic mail system & 2.41 & 1.20 \\
\hline Automated material handling system (hardware) & 1.69 & 0.92 \\
\hline Advanced planning and scheduling software & 1.44 & 0.79 \\
\hline Electronic data interchange (EDI) capability & 1.44 & 0.79 \\
\hline Enterprise Resource Planning systems (ERP) system & 1.44 & 0.75 \\
\hline E-procurement system & 1.31 & 0.63 \\
\hline Bar coding/automatic identification system & 1.25 & 0.56 \\
\hline Transportation/warehouse management software & 1.16 & 0.51 \\
\hline Forecast/demand-management software & 1.13 & 0.41 \\
\hline
\end{tabular}

Table 3. Level of ICT infrastructure

Implementing supply chain integration practices in manufacturing systems is not an easy task. In the literature, researchers have pointed out a number of challenges or obstacles for implementing supply chain integration practices in the firms of developing country scenarios. For any change in an organization to take hold and success, the challenges or barriers need to be identified and understood. The questions were set up on a four-point scaled range to measure the extent of challenges described by each of the items. The scaled range from 1 to 4 , with $1=$ very low challenge, 2 = low challenge, $3=$ challenge, and $4=$ high challenge. The supply chain integration practices challenges and barriers are analyzed based on the experiences of the respondent companies. The three main barriers in firms are: the excising model specificity to the developed countries' operating environment, Quality of skilled workforce, and Lack of ICT infrastructure. Table 4 shows the ratings of the most significant challenges or obstacles to implementing supply chain integration practices according to the respondents. 


\begin{tabular}{|l|c|c|}
\hline \multicolumn{1}{|c|}{ Types of Enablers } & Mean & S.D. \\
\hline The excising model specificity to the developed countries operating environment & 2.97 & 0.76 \\
\hline Quality of skilled and cost effective workforce & 2.94 & 0.84 \\
\hline Lack of ICT infrastructure & 2.93 & 0.78 \\
\hline Difficulty to implement the models \& handle for practical operations & 2.79 & 0.89 \\
\hline Non systematic approach to measuring customer requirements & 2.78 & 0.74 \\
\hline Management practices and organizational working culture & 2.77 & 0.91 \\
\hline Difficult to establish relationships based on shared risks \& rewards & 2.68 & 0.86 \\
\hline Lack of employee loyalty/motivation/empowerment & 2.57 & 0.88 \\
\hline Lack of physical infrastructure & 2.45 & 0.91 \\
\hline
\end{tabular}

Table 4. The challenges of supply chain integration

\section{Conclusions and suggestions for future research}

In this paper, the concept of supply chain integration has been discussed for its great potential to improve the manufacturing industries in developing countries focusing in Ethiopia. In today's competitive business, firms in developing countries are started to realize the real competition is not firm-versus-firm, but supply chain-versus-supply chain. Hence, it is important for firms to improve their level of integration within and alongside of their supply chains. The current concern is how to integrate supply chains rather than why integration. A result of the literature has presented about the basic concepts and the characteristics of supply chain integration. Costs and Benefits of supply chain integrating in businesses are presented. Most of the existing literature is rich with research and development efforts that upgrade the firms in developed countries supply chain. However, most of the research results did not try to include the firms in developing countries that help supply chain improvement efforts that include whole supply chain members to solve various common problems.

The results of industrial questionnaire survey were conducted to examine the experience of representative manufacturing industries. Based upon the findings of the research work, the companies investigated seem to be oriented towards integration inside the organization. Results revealed that degree of integration is low when it comes to Ethiopian firms but it is some promising initiatives are undergoing. The existing practices have shown that firms have managed the information flows in a number of ways, mainly telephone, mobile, letters, telex, and faxes over the years. More recently, firms have started using the internet to create connections with imported material suppliers for their foreign purchases, even though telephone and fax are also still dominant ways of communication. In contrast to the current dominant manual interactions the real supply chain integration requires information systems that facilitates a great deal of data input, both from automated sources such software applications and RFID. In the survey responses, it was clearly observed that a lower level of ICT implementation in the companies. However, respondent companies did not consider it as big challenges for supply chain integration. This discrepancy can be explained with two main 
reasons. The first one, some companies have assumed that they have already basic ICT infrastructure availability which did not exploit well. The other explanation for the differences in the responses was the lower level of awareness on the importance and relationship of ICT and supply chain integration success.

The findings show the developing countries have also additional challenges related to low level of awareness and knowledge, expertise and professional support and lack of physical and ICT infrastructure on the firms for their both internal and external integration with suppliers and customers within the firms investigated. Therefore, the firms need to enhance the information sharing capability and upgrade the existing ones.

Several research agenda can be raised to advance the understanding of supply chain integration that can improve its practice especially in developing countries. One of the areas to examine involves how effectively developing countries firms integrated within the organization and with their suppliers and customers. Since it is almost impossible to integrate the whole components of a supply chain in the existing enablers and capabilities, future research should identify the factors that facilitate and hinder the success of integrated supply chain. It is also important to identify the most appropriate techniques that facilitate the modeling and the process of integration. According to the research results, it is important to address how the existing models suit the firms in developing countries to further integrate the entire supply chain involving unique characteristics.

\section{References}

Asche, H., \& Schüller, M. (2008). China's Engagement in Africa: Opportunities and Risks for Development. GTZ.

Auramo, J., Kauremaa, J., \& Tanskanen, K. (2005). Benefits of IT in supply chain managementan explorative study of progressive companies. International Journal of Physical Distribution \& Logistics Management, 35(2), 82-100. http://dx.doi.org/10.1108/09600030510590282

Awad, H.A.H., \& Nasar, M.O. (2010). A Broader view of the supply chain integration challenges. International Journal of Innovation, Management \& Technology, 1(1), 51-56.

Bowersox, D.J., Closs, D., \& Stank, T.P. (2001). 21st Century Logistics: Making Supply Chain and Integration. 2nd Edition. Boston, MA: Harvard Business School Press.

Chopra, S., \& Meindl, P. (2001). Supply Chain Management, Upper Saddle River, NJ. PrenticeHall, Inc. 33-37. 
COMTD (Committee on Trade and Development). (1996). Participation of developing countries in World Trade: Overview of major trends and underlying factors. World Trade Organization.

Dolan, C., \& Humphrey, J. (2004). Changing Governance Patterns in the Trade in Fresh Vegetables between Africa and the United Kingdom. Environment and Planning, 36, 491-509. http://dx.doi.org/10.1068/a35281

Fawcett, S.E., \& Magnan, G.M. (2001). Achieving World-Class Supply Chain Alignment: Benefits, Barriers, and Bridges. CAPS Research/Institute for Supply Management, Tempe, AZ.

Fleury, A., \& Fleury, M.T. (2001). Alternatives for industrial upgrading in global value chains: The case of the plastics industry in Brazil. Ids Bulletin-Institute of Development Studies, 32(3), 116-126. http://dx.doi.org/10.1111/j.1759-5436.2001.mp32003012.x

Frohlich, M., \& Westbrook, R. (2001). Arcs of integration: An international study of supply chain strategies.Journal of Operations Management, 19, 185-200. http://dx.doi.org/10.1016/S0272-6963(00)00055-3

Gereffi, G., \& Lee, J. (2012). Why the World Suddenly Cares About Global Supply Chains. Journal of Supply Chain Management, 48(3), 24-32. http://dx.doi.org/10.1111/j.1745493X.2012.03271.x

Gunasekaran, A. (2004). Supply chain management: Theory and applications. European Journal of Operational Research, 159, 265-268. http://dx.doi.org/10.1016/j.ejor.2003.08.015

Han, D., Kwon, I.W.G., Bae, M., \& Sung, H. (2002). Supply chain integration in developing countries for foreign retailers in Korea: Wal-Mart experience. Computer and Industrial Engineering, 43, 111-121. http://dx.doi.org/10.1016/S0360-8352(02)00070-0

Hosseini, S.M., Aziz, S., \& Sheikhi, N. (2012). An investigation on the effect of supply chain integration on competitive capability: An empirical analysis of Iranian food industry. International Journal of Business \& Management, 7(5), 73-90.

Hugo, W.M.J., Badenhorst-Weiss, J.A., \& Van Biljon, E.H.B. (2004). Supply Chain Management: Logistics in Perspective. Pretoria: Van Schaik.

Humphrey, J. (2004). Upgrading in global value chains. Working Paper No. 28, Policy Integration Department World Commission on the Social Dimension of Globalization, International Labour Office.

Ivarsson, I., \& Alvstam, C.G. (2005). Technology transfer from TNCs to local suppliers in developing countries: a study of AB Volvo's truck and bus plants in Brazil, China, India, and Mexico. World Development, 33(8), 1325-1344. http://dx.doi.org/10.1016/j.worlddev.2005.04.011 
Jharkharia, S., \& Shankar, R. (2005). IT-enablement of supply chains: Understanding the barriers. The Journal of Enterprise Information Management, 18(1), 11-27. http://dx.doi.org/10.1108/17410390510571466

Katunzi, T.M., (2011). Obstacles to Process Integration along the Supply Chain: Manufacturing Firms Perspective. International Journal of Business and Management, 6(5), 105-113.

Kim, S.W. (2006). Effects of supply chain management practices, integration and competition capability on performance. Supply Chain Manag. Inter. J., 11(3), 241-248. http://dx.doi.org/10.1108/13598540610662149

Kureshi, N. (2010). Supply chain integration of manufacturing SMEs - The logic and need in developing economies. 4th scientific quality congress Middle East Proceedings.

Lambert, D.M., \& Cooper, M.C. (2000). Issues in supply chain management. Industrial Marketing Management, 29(1), 65-83. http://dx.doi.org/10.1016/S0019-8501(99)00113-3

Lee, C.W., Kwon, I.G., \& Severance, D. (2007). Relationship between supply chain performance anddegree of linkage among supplier, internal integration and customer, supply chain management. Inter. J., 12(6), 444-452.

McLaren, T.S., Head, M.M., \& Yuan, Y. (2004). Supply chain management information systems capabilities: an exploratory study of electronics manufacturers. Information Systems an e-Business Management, 2, 207-222. http://dx.doi.org/10.1007/s10257-004-0035-5

McLaren, T., (2006). A measurement model for web-enabled supply chain integration. 19th Bled eConference eValues, Bled, Slovania.

Moncrieff, B., \& Stonich, M. (2001). Supply-Chain Maturity Model and Performance Assessment, November. Retrieved from http://www.supply-chain.org

Monczka, R., Handfield, R., Giunipero, L.C., Patterson, J.L. \& Waters, D. (2010). Purchasing and Supply Chain Management. 4th edition. Hampshire, UK: Cengage Learning.

Naude, M.J., \& Badenhorst-Weiss, J.A. (2011). Supply chain management problems at South African automotive component manufacturers. South. Africa Business Review, 15(1), 70-99.

Özdemir, A.I., \& Aslan, E. (2011). Supply chain integration, competition, capability and business performance: a study on Turkish SMEs. Asian of Business Management, 3(4), 325-332.

PE Consulting. (1997). Efficient Consumer Response: Supply Chain Management for the New Millennium? London: Institute of Logistics.

Poirier, C.C., \& Bauer, M. J., (2001). E-Supply Chain: Using the Internet to Revolutionize Your Business. San Francisco, CA: Berrett-Koehler Publishers. 
Roloff, M., Gailius, S., Ibarra, P., \& Polese, W. (2001). Stage of Maturity Correlates with Performance, Profitability, and Sales Growth. Signals of Performance, 2(6), 1-5.

SCC (Supply Chain Council's). (2010). Supply Chain Operations Reference model (SCOR). available at: www.supply-chain.org

Simchi-Levi, D., Kaminsky, P., \& Simchi-Levi, E. (2003). Designing and Managing the Supply Chain. Concepts, Strategies, and Case Studies. New York: Irwin McGraw-Hill.

Stanley, E., Gregory, M., \& Mathew, M. (2005). Benchmarking information integration in supply chain management. A multi-channel approach, 47-51.

Stevens, G.C. (1989). Integrating the supply chain. International Journal of Physical Distribution and Materials Management, 19(8), 3-8. http://dx.doi.org/10.1108/EUM0000000000329

The Conference Board. (2009). Integration of Developing Countries in Global Supply Chains: A Global Buyers' and Producers' Perspective. The World Bank 2009.

Trienekens, J.H. (2011). Agricultural Value Chains in Developing Countries: A Framework for Analysis. International Food and Agribusiness Management Review, 14(2), 51-82.

Wisner, J., Leong, G.K., \& Tan, K.C. (2006). Principles of Supply Chain Management. A Balanced Approach. Beijing, Thomson.

Journal of Industrial Engineering and Management, 2014 (www.jiem.org)

Article's contents are provided on a Attribution-Non Commercial 3.0 Creative commons license. Readers are allowed to copy, distribute and communicate article's contents, provided the author's and Journal of Industrial Engineering and Management's names are included. It must not be used for commercial purposes. To see the complete license contents, please visit http://creativecommons.org/licenses/by-nc/3.0/. 